\title{
Genetics of Floral Longevity in Petunia
}

\author{
Kimberly H. Krahl and William M. Randle \\ Department of Horticulture, University of Georgia, Athens, GA 30602
}

Additional index words. Petunia hybrida, P. integrifolia, P. axillaris, flower life, diallel, combining ability, gene effects

\begin{abstract}
Petunia hybrida Vilm. is one of the major bedding plants grown worldwide, and, like most bedding plants, is grown primarily for its seasonal floral display. While increased floral and reflowering capacity have been the focus of breeding programs for many ornamental species, floral longevity has received little direct attention. Increased floral longevity would enhance the value of any crop grown for floral effect. In this study, four parental genotypes (two with short flower life, two with long flower life) were crossed in a partial diallel mating design to create $\operatorname{six} F_{1}$ families. The $F_{1}$ individuals were then selfed and backcrossed to the appropriate parents to create $F_{2}$ and backcross families. Data from parental and $F_{1}$ genotypes were analyzed to determine general and specific combining ability for floral longevity in petunia. Results indicated the presence of significant additive gene effects and nonsignificant nonadditive gene effects for floral longevity in this germplasm. However, aberrant $F_{2}$ and backcross family means were observed in all families. For each family, $F_{2}$ and backcross means were lower than expected given normal Mendelian segregation. Further experiments will be necessary to elucidate the causes for the deviate $F_{2}$ and backcross family means before specific recommendations for selecting for increased floral longevity in petunia can be made.
\end{abstract}

Herbaceous plant species valued primarily for their ornamental effects are often prized most highly for their floral display. Many floral qualities, such as color, size, and form, have been the focus of major breeding programs for many ornamental crops. Additionally, breeding in many species has increased the length of the flowering period and the ability to reflower. Floral longevity has received very little attention from ornamental plant breeders. The one exception is gerbera (Gerbera sp.), a popular garden, pot, and cutflower plant, for which several studies have been conducted to determine the genetic basis of floral longevity (DeJong and Garretsen, 1985; Harding et al., 1981; Wernett et al., 1996). Selection of genotypes with increased floral longevity in addition to floral prolificacy would add greatly to the ornamental value of these crops. In this study, sources of variability for and the genetics of floral longevity were examined in Petunia hybrida.

\section{Materials and Methods}

In a preliminary experiment, 11 Petunia hybrida breeding lines, three accessions of $P$. integrifolia (Hook.), and two accessions of $P$. axillaris (Lam.) were screened for length of detached flower life (data not shown). The breeding line MSP1 of $P$. hybrida and the accession NSL98077 of $P$. integrifolia were selected as parents exhibiting long detached flower life. Two accessions, NSL88813 of $P$.

\footnotetext{
Received for publication 19 Aug. 1998. Accepted for publication 20 Oct. 1998. The cost of publishing this paper was defrayed in part by the payment of page charges. Under postal regulations, this paper therefore must be hereby marked advertisement solely to indicate this fact.
}

integrifolia and NSL88812 of P. axillaris, were selected as parents exhibiting short detached flower life. The parent lines were highly inbred and presumed to be homozygous. Seed of the three petunia accessions was obtained from the U.S. Seed Storage Laboratory, Fort Collins, Colo. Seed of the petunia breeding line MSP1 was donated by Dr. Lowell Ewart of Michigan State.

The four parental lines were crossed in a partial diallel (no selfs, no reciprocals) mating design to produce six $F_{1}$ families. The $F_{2}$ progeny for each cross were obtained by selfing $F_{1}$ plants. The $F_{1}$ plants were backcrossed to the respective parents to create 12 backcross families.

Plants were grown in $15.2-\mathrm{cm}$ plastic pots and assigned randomly to bench space in the greenhouse at the Univ. of Georgia, Athens, using standard horticultural practices for petunia. Greenhouse temperature was set at $27^{\circ} \mathrm{C}$ and maintained with fans and cooling pads. Plants were $\approx 3$ months old at time of flower harvest in July 1994. Three newly expanded flowers were collected from each plant and placed in $16 \times 125 \mathrm{~mm}$ test tubes filled with deionized water in the laboratory under constant fluorescent lighting and $21^{\circ} \mathrm{C}$. Flowers were collected three times (three replications) from 10 parental, $10 \mathrm{~F}_{1}, 35 \mathrm{~F}_{2}$, and $25 \mathrm{BC}$ plants in July 1994. Detached flower longevity (DFL) was calculated as days to the first sign of corolla wilting. As a comparison, three newly expanded attached flowers were tagged on the four parental genotypes in the greenhouse. Attached flowers were tagged three times (three replications) and attached flower longevity (AFL) was calculated as days to the first sign of corolla wilting.

Parental means were analyzed using analysis of variance. Spearman's correlation coefficients were used to assess consistency of parental rank order for DFL and AFL. Parental and $F_{1}$ family means were analyzed with Duncan's multiple range test. The four long $x$ short DFL families were analyzed using Griffing's (1956) method 1, model 4 procedure for diallel analysis. General and specific combining ability (GCA and SCA, respectively) were calculated.

\section{Results and Discussion}

Detached floral longevity was selected for genetic analysis because of the unknown effect flower load on a single plant might have on AFL. Analysis of variance revealed significant differences in DFL among the parental genotypes. However, the two DFL parents, NSL88812 and NSL88813, did not differ significantly (Table 1). Ranking of parents remained the same for DFL and AFL, with attached flowers surviving an average of $3 \mathrm{~d}$ longer than did detached flowers (Table 1). Means for three of the six $F_{1}$ family means (NSL98077 x NSL88813, MSP1 x NSL98077, and NSL98077 x NSL88812) were intermediate between their respective parental means and significantly different from both parents (Table 1 ). The remaining three $F_{1}$ family means (MSP1 1 NSL88813, MSP1 $\times$ NSL88812, and NSL88813 x NSL88812) did not differ significantly from one of the respective parental means.

Estimates of GCA and SCA were obtained from diallel analysis for the four parents and their six $F_{1}$ hybrids (Table 2). General combining ability is a measure of a parental genotype's average performance in a hybrid cross (Sprague and Tatum, 1942), and provides an estimate of additive gene action. Specific combining ability is a measure of the deviation of individual hybrid crosses from average hybrid performance (Sprague and Tatum, 1942) and provides an estimate of nonadditive gene action.

Table 1. Longevity (in days) of attached and detached flowers of four petunia inbreds and of detached flowers of their $F_{1}$ hybrids.

\begin{tabular}{|c|c|c|}
\hline Genotype & Attached & Detached \\
\hline NSL98077 & $8.0 \mathrm{a}^{\mathrm{z}}$ & $6.7 \mathrm{a}$ \\
\hline NSL98077 x NSL88813 & & $5.5 \mathrm{~b}$ \\
\hline MSP1 x NSL98077 & & $5.1 \mathrm{bc}$ \\
\hline MSP1 x NSL88813 & & $4.2 \mathrm{~cd}$ \\
\hline MSP1 x NSL88812 & & $4.1 \mathrm{~cd}$ \\
\hline MSP1 & $7.0 \mathrm{~b}$ & $4.0 \mathrm{~d}$ \\
\hline NSL98077 x NSL88812 & & $3.7 \mathrm{de}$ \\
\hline NSL88813 x NSL88812 & & 2.8 ef \\
\hline NSL88812 & $6.1 \mathrm{c}$ & $1.8 \mathrm{fg}$ \\
\hline NSL88813 & $5.3 \mathrm{~d}$ & $1.6 \mathrm{~g}$ \\
\hline
\end{tabular}

${ }^{2}$ Mean separation within columns by Duncan's multiple range test, $P=0.05 ; \mathrm{n}=39$ for each genotype.

Table 2. Analysis of variance of general and specific combining ability (GCA and SCA, respectively) components of detached flowers of petunia in a four-parent partial diallel mating system.

\begin{tabular}{lrcc}
\hline \hline Source & df & MS & F \\
\hline Rep & 2 & 0.04 & 0.06 \\
Hybrids & 5 & 2.91 & $4.28^{*}$ \\
GCA & 3 & 3.81 & $5.60^{*}$ \\
SCA & 2 & 1.57 & 2.31 \\
Error & 10 & 0.68 & \\
\hline
\end{tabular}

"Significant at $P=0.05$. 
The estimate for GCA was significant (Table 2), suggesting the importance of additive gene action in floral longevity, whereas that for specific combining ability was not, suggesting a lack of importance of nonadditive gene action in floral longevity for the genotypes tested. General combining ability accounted for $79 \%$ of the total genotypic variation. The presence of significant additive gene action for floral longevity indicated that selection for increased floral longevity would be possible in petunia.

Although significant general combining ability for floral longevity has been detected in gerbera, estimates of heritability have been moderately low. Harding et al. (1981) used half-sib families and parents to calculate heritability for floral longevity. Broad and narrow sense heritability estimates were moderately low (broad sense heritability, $36 \%$ and $46 \%$; narrow sense heritability, $0 \%, 24 \%$, and $38 \%$ ). Harding et al. (1981) concluded that progress in selection for increased floral life in gerbera would be possible only under intense selection or over many generations. De Jong and Garettsen (1985) used gerbera parents and $F_{1}$ progeny to estimate general- and specificcombining ability for two components of vase life. Both components exhibited significant general and nonsignificant specific combining ability. De Jong and Garretsen (1985) concluded that development of gerbera cultivars with increased floral longevity should be possible. Wernett et al. (1996), using a $5 \times 5$ diallel mating system, reported significant general and nonsignificant specific combining ability for floral longevity. Broad and narrow sense heritability were both estimated to be 0.28 . They concluded that although heri-
Table 3. Generation means ${ }^{z}$ and standard errors for longevity of detached flowers of six petunia crosses.

\begin{tabular}{lccccccc}
\hline \hline Generation & $\begin{array}{c}\text { No. of } \\
\text { plants }\end{array}$ & $\begin{array}{c}\text { NSPP1 x } \\
\text { NSL9877 }\end{array}$ & $\begin{array}{c}\text { MSP1 x } \\
\text { NSL8813 }\end{array}$ & $\begin{array}{c}\text { NSP1 x } \\
\text { NS8812 }\end{array}$ & $\begin{array}{c}\text { NSL98077 x } \\
\text { NSL88813 }\end{array}$ & NSL98077 x & NSL888813 x \\
\hline $\mathrm{P}_{1}$ & 30 & $4.0 \pm 0.9$ & $4.0 \pm 0.9$ & $4.0 \pm 0.9$ & $6.7 \pm 1.4$ & $6.7 \pm 0.4$ & $1.6 \pm 0.8$ \\
$\mathrm{P}_{2}$ & 30 & $6.7 \pm 1.4$ & $1.6 \pm 0.8$ & $1.8 \pm 0.4$ & $1.6 \pm 0.8$ & $1.8 \pm 0.4$ & $1.8 \pm 0.4$ \\
$\mathrm{~F}_{1}$ & 30 & $5.1 \pm 0.9$ & $4.2 \pm 1.0$ & $4.1 \pm 1.1$ & $5.5 \pm 1.4$ & $3.7 \pm 1.0$ & $2.8 \pm 1.0$ \\
Midparent & & 5.35 & 2.80 & 2.90 & 4.15 & 4.25 & 1.70 \\
$\mathrm{~F}_{2}$ & 105 & $2.3 \pm 0.6$ & $2.2 \pm 0.4$ & $2.3 \pm 0.8$ & $3.7 \pm 1.1$ & $2.5 \pm 0.6$ & $2.1 \pm 0.3$ \\
$\mathrm{BCP}_{1}$ & 75 & $2.8 \pm 0.8$ & $2.4 \pm 0.5$ & $2.8 \pm 0.6$ & $3.4 \pm 1.0$ & $3.2 \pm 1.0$ & $2.1 \pm 0.6$ \\
$\mathrm{BCP}_{2}$ & 75 & $3.0 \pm 0.9$ & $2.4 \pm 0.5$ & $2.4 \pm 0.5$ & $2.6 \pm 0.8$ & $2.4 \pm 0.5$ & $2.3 \pm 0.6$ \\
\hline
\end{tabular}

${ }^{\mathrm{z}}$ Mean days to corolla wilting.

tability estimates were low, floral longevity could be increased under intense selection if parents with good combining ability were used.

While $F_{1}$ family means for floral longevity for all six petunia crosses were distributed between the respective parental means, $\mathrm{F}_{2}$ and backcross family means for all six families were aberrant (Table 3). Given normal Mendelian segregation, $\mathrm{F}_{2}$ means are expected to be intermediate between parental means, and backcross means are expected to be intermediate between the $F_{1}$ and the respective parental means. However, $\mathrm{F}_{2}$ and backcross means for all six petunia families consistently exhibited lower than expected means (Table 2). No simple explanation for these aberrant segregation patterns was apparent. Skewed segregation ratios could possibly be the result of aneuploidy, or incomplete pairing and/or crossing over of homologous chromosomes.

In summary, significant variation exists in petunia for floral longevity. Diallel analysis of this petunia germplasm revealed significant additive gene effects for floral longevity, indicating that progress in selection for increased floral longevity should be possible. However,
$\mathrm{F}_{2}$ and backcross family means for floral longevity of each cross were lower than expected given normal Mendelian segregation. Further experimentation is necessary to elucidate the mechanisms causing the deviate $\mathrm{F}_{2}$ and backcross family means before specific recommendations for manipulating floral longevity can be made.

\section{Literature Cited}

De Jong, J. and F. Garretsen. 1985. Genetic analysis of cut flower longevity in gerbera. Euphytica 34:779-784.

Griffing, B. 1956. Concept of general and specific combining ability in relation to diallel crossing systems. Austral. J. Biol. Sci. 9:463-493.

Harding, J., T. Byrne, and R.L. Nelson. 1981. Heritability of cut-flower vase longevity in gerbera. Euphytica 30:653-657.

Sprague, G.F. and L.A. Tatum. 1942. General vs. specific combining ability in single crosses of corn. J. Amer. Soc. Agron. 34:923 -932.

Wernett, H.C., G.J. Wilfret, T.J. Sheehan, P.M. Lyrene, F.G. Martin, T.L. White, G.L. Powell, and C.J. Wilcox. 1996. Postharvest longevity of cut-flower Gerbera. II. Heritability of vase life. J. Amer. Soc. Hort. Sci. 121:222-224. 